\title{
Regional variations in ore composition and fluid features of massive sulphide deposits in South China: Implications for genetic modelling
}

\author{
Department of Earth Sciences, State Key Laboratory for Mineral Deposit Research, Nanjing University, Nanjing 210093, China
}

Upper Palaeozoic intracontinental massive sulphide deposits occur in both the Lower Yangtze River and the Nanling Mountain regions of South China. However, sulphide ores of these two regions are remarkably different in composition. Ores of the Lower Yangtze region are copper-rich with minor $\mathrm{Pb}$ and $\mathrm{Zn}$ and recoverable $A u, A g$, Co and Mo; they usually have low concentrations of radiogenic lead and have tight $\delta^{34} S$ distribution patterns close to zero. Fluid inclusions are highly saline and sodium-rich. Ores of the Nanling Mountain region mainly comprise $\mathrm{Pb}, \mathrm{Zn}, \mathrm{Sn}$ and $\mathrm{W}$ as well as $\mathrm{Cu}$ with recoverable $\mathrm{Ag}, \mathrm{Sb}, \mathrm{Hg}, \mathrm{U}, \mathrm{Bi}, \mathrm{Tl}$ and $\mathrm{Mo}$; they usually have higher concentrations of radiogenic lead and wide-ranging $\delta^{34} S$ values. Their fluid inclusions have low salinities and are potassium-rich.

There is evidence to indicate that the Upper Palaeozic continental crust in the Lower Yangtze region has lower maturity than that of the Nanling Mountain region. The compositional contrasts between these two regions are suggested to have been controlled by differences in their basin basements and thus reflect the difference in crustal maturity during ore formation.

\section{Introduction}

It has long been recognized that the composition and geological features of massive sulphide deposits were substantially affected by the nature of the crust upon which they were formed (Ishihara and Terashima, 1974; Sawkins, 1976; Hutchinson, 1980), as well as by the composition of basin basement (Russell, 1968; Ishihara and Terashima, 1974). The three major types of massive sulphides, i.e. the Cyprus-, Kuroko- and Sullivan-types were considered by Sawkins (1976) to represent products on ocean ridges, island arcs and intracontinental basins, respectively. Fouquet et al. (1993) noted that variations in composition of modern massive sulphide deposits are related to their formation in back-arc systems of different maturity. However, discussions on regional variations of massive sulphides and their relationships to the continental crust are rare. The present contribution aims to discuss the differences between massive sulphides in the Lower Yangtze River and the Nanling Mountain regions and to connect their genesis with continental evolution and crustal maturity.

\section{Geological setting}

There exist more than 20 major massive sulphide base-metal deposits (Figure 1) in the Upper Palaeozoic marine fault-bounded depression troughs developed on post-Caledonian continental crust.

According to Guo and co-workers (1980), the triangular Dabie craton which is located to the north of the Yangtze River and belongs to the south part of the North China plate (Figure 1) is composed of Late Archaean to Early Proterozoic metamorphic rocks. During the Mid-Proterozoic the South China oceanic plate was subducted northwards beneath the North China plate, resulting in the northeasttrending island arc system, i.e., the Changsha- Qianyang belt. This belt is represented by a thick sequence of calc-alkalic and spilitickeratophyric volcanites and flysch sediments with fragments of ophiolites. The Lower Palaeozoic subduction zone is marked by the northeast-trending fault that passes through Zhenghe and Dapu in Fujian Province (Figure 1). The Late Proterozoic to Early Palaeozoic flysch with spilitic-keratophyric intercalations northwest of that fault were formed in an arc-trench-basin environments.

A northeast-trending Mesozoic volcanic belt (Figure 1), which is part of the circum-Pacific magmatic zone, extends along the southeastern coast of China. There has been heated debate regarding the tectonics of the basement beneath the volcanic cover. Guo and co-workers (1980) suggested that the basement rocks, which have suffered greenschist- to amphibolite-facies metamorphism, may represent an active Hercynian-Indosinian continental margin. In contrast, an exotic Precambrian terrane is inferred by others based mainly on U-Pb isotope dates between 1.0 and $2.0 \mathrm{Ga}$ (Ma and Sun, 1985; Shui, 1987; Zhang, 1991; Li, 1997).

Towards the end of the Early Palaeozoic (Caledonian orogeny), the continental crust of South China stabilized (Gu and Xu, 1987). Subsidence of the crust during the Late Palaeozoic resulted in marine transgression from the southwest to the northeast. Based upon their relationships to the basements on which they were initiated, Shi et al. (1963) distinguished two types of fault-bounded sedimentary basins: inherited and superimposed. The Xinjiang, Pingxiang-Leping, West Fujian, North Guangxi and North Guangdong basins (Figure 1) are of the superimposed type where Upper Palaeozoic sediments are separated by a sharp unconformity either from the folded Lower Palaeozoic sequences or directly from the metamorphosed Mid-Proterozoic basement. The Lower Yangtze basin (Figure 1), on the other hand, is of the inherited type, which was formed by continued development of a pre-existing Caledonian basin. In this case there is no angular unconformity between the Lower and the Upper Palaeozoic sequences (Xu and Zhu, 1978). During the Hercynian-Indosinian cycle, both the superimposed and inherited basins generally received several thousand metres of sediments, predominantly carbonates and clastic rocks (Xu and Zhu, 1978). Most of the massive sulphide ore layers occur $50 \sim 200 \mathrm{~m}$ above the base of the upper Palaeozoic successions. Volcanic intercalations, mainly of basalts, dacites and rhyolites, have been identified within these sequences in many places 


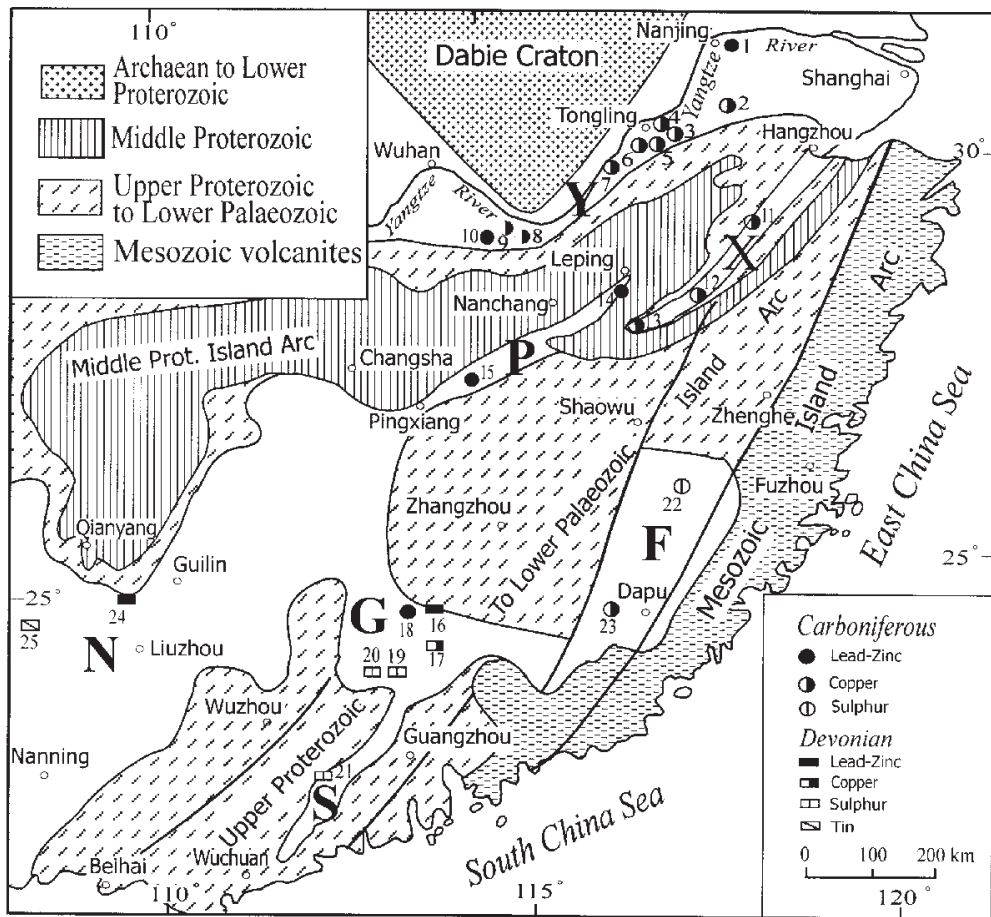

Figure 1 Locations of major Upper Palaeozoic massive sulphide deposits in South China. Hercynian-Indosinian Basins: F-West Fujian; G-North Guangdong; N-North Guangxi; P-Pingxiang-Leping; X-Xinjiang; Y-Lower Yangtze; S-Sihui-Wuchuan. Massive Sulphide Deposits: 1-Qixiashan; 2-Magushan (East Tongshan); 3-Xingqiao; 4-Tongguanshan;

5- Dongguashan; 6-Mashan; 7-West Tongshan; 8-Chengmenshan; 9-Wushan; 10-Yinshan; 11-Linghou; 12-Yongping; 13-Dongxiang; 14-Lehua; 15-Qibaoshan; 16-Fankou; 17-Dabaoshan; 18-Yangliutang; 19-Xiniu; 20-Hongyan; 21-Dajiangping; 22-Longfengchang; 23-Yushui; 24-Shiding; 25-Dachang.

(Gu et al., 1993), Andesitic volcanites are not important in these basins, and the petrological association is bimodal. Hence, these basins may represent the initial stage of continental rifting (Sawkins, 1976; Gu and Yang, 1989).

The Upper Palaeozoic sediments in these basins are largely unmetamorphosed although folding took place during the Late Triassic (Indosinian) compression. During the Mesozoic time, extensive volcanism and granite intrusion occurred all over SE China.

\section{General features of the massive sulphide deposits in South China}

The geology and genesis of the massive sulphide deposits in South China have been described by many authors (Xu and Zhu, 1978; Hsu et al. 1980; Wang et al., 1986; Gu et al., 1993; Yue et al., 1993). These deposits mainly occur in the transitional horizons from clastic to carbonatic sequences which represent Upper Palaeozoic marine transgression of the fault-bounded basins ( $\mathrm{Gu}$ and Xu, 1987; Hu et al, 1994). Since basin subsidence occurred progressively later towards the north, occurrences of massive sulphides are found at progressively higher positions in the sedimentary columns in that direction with predominantly Devonian in the Nanling Mountain region, lower Carboniferous in the Xinjiang River region and middle Carboniferous along the Yangtze River (Gu et al., 1993). Volcanites, basaltic, dacitic and rhyolitic in composition have been reported in the ore-hosting horizons (Fu, 1977; Zhu and Zhang, 1981; Gu and $\mathrm{Xu}, 1984)$. Compositionally, the South China deposits have considerable reserves of tin and tungsten as well as copper, lead, zinc, gold and silver (Gu et al., 1993). The distribution of metals and ore minerals in these deposits exhibits stratigraphically vertical and lateral zonations (Gu, 1984): The general trend of metal zonation from the base upwards is Fe (sulphides) $\mathrm{Cu}-(\mathrm{Cu}, \mathrm{W})-\mathrm{Pb}, \mathrm{Zn}-\mathrm{Fe}, \mathrm{Mn}$ (carbonates and/or oxides) (W). Laterally from the feeders, they show a trend of $\mathrm{Cu}, \mathrm{S}$ (W) $-\mathrm{Pb}, \mathrm{Zn}, \mathrm{Ag}-\mathrm{Fe}, \mathrm{Mn}$. These zonations are thought to be produced by a combination of sedimentation, diagenesis, remobilization, and late stage superimposition (Gu et al., 1993). Underlying the stratiform ores in some of the deposits are fissure-filling, breccia-cementing and impregnated mineralizations representing the submarine hydrothermal feeders. Alterations genetically related to footwall mineralizations include silicification, sericitization and K-feldspathization, which were interpreted to reflect the silica- and potassium-rich nature of the continental crust ( $\mathrm{Gu}$ and Yang, 1989), and which might have been prompted by the nucleii in the footwall quartzofeldspathic clastic sediments. Being formed contemporaneously with the sulphide deposits, stratiform iron and manganese ores occur in relatively oxidizing environments within the same basins. Locally, such iron and manganese ores are underlain by cross-cutting lead-zinc veins that may represent the hydrothermal feeders $(\mathrm{Gu}$, 1987a).

\section{Contrasting ore composition and fluid features of two regions}

Although the Upper Palaeozoic massive sulphide deposits in South China share many common features, there are strong contrasts in ore composition and fluid features between those in the Nanling Mountain and the Lower Yangtze River regions.

\section{Metal components}

The ore deposits in the Lower Yangtze region are characterized by massive copper sulphide ores (Figures 1,2 and Table 1), such as those at Wushan (1.3 Mt Cu, avg. 1.3\%) and Dongguashan $(0.94 \mathrm{Mt} \mathrm{Cu}$, avg. $1.0 \%)$. Gold is an important by-product in these deposits ( $0 . n$ to $n$ ppm, e.g., at Wushan, Chengmenshan, Tongguanshan, Xinqiao, Dongguashan and Qixiashan). Locally, gold is economically much more important than base metals, and has formed a separate gold deposit at Mashan (6 tons Au, avg. 9.6g/t). The deposit at Qixiashan also has significant reserves of gold. Cobalt and molybdenum are also recoverable in some of the deposits (Table 1). However, none of these deposits have significant concentration of fluorine, boron, uranium, mercury, bismuth, antimony, thallium and tin. Only a small mine at Longjiaoshan to the southeast of Wuhan is reported to have recoverable tungsten.

By contrast, massive sulphide ores in the Nanling Mountain region (Figure 1) have lead, zinc and silver reserves economically more important than copper and gold (Table 1). Examples include Fankou (3.4 Mt $\mathrm{Zn}$ and $1.7 \mathrm{Mt} \mathrm{Pb}$ ), Yangliutang, Siding and Dachang. The ores are usually also enriched in fluorine, boron, uranium, mercury, bismuth, antimony and thallium. The fluorine concentration is normally higher than $280 \mathrm{ppm}$ in the ores of the region and even reaches $1.65 \%$ in the low-grade sulphur ores from the Jingtan deposit in the North Guangdong basin. The Dachang tin-polymetallic deposit is characterised by boron enrichment. Tourmaline is a common constituent in the stratiform sulphide ores and their host siliceous rocks with banded tourmalinites containing >20 vol. $\%$ tourmaline being present locally (Han et al., 1997; Jiang et al., 1999). Uranium is considerably higher in the Fankou and Siding deposits of the Nanling Mountain region (Tu et al., 1984). Mercury is of high enough grade to be economic in the massive lead-zinc ore (avg. 135 ppm) of Fankou mine (Huang, 1989). Analyses of various 
Table 1. Comparison between the Lower Yangtze and the Nanling Mountain regions in ore metals in massive sulphide deposits.

\begin{tabular}{clll}
\hline Region & Deposit & Principal metals & Associating metals \\
\hline \multirow{4}{*}{ Lower } & Mashan & $\mathrm{Au}$ & $\mathrm{Cu}, \mathrm{Co}$ \\
Yang- & Tongguashan & $\mathrm{Cu}$ & $\mathrm{Au}, \mathrm{Ag}, \mathrm{Co}$ \\
tze & Tongshan & $\mathrm{Cu}$ & $\mathrm{Au}, \mathrm{Co}, \mathrm{Mo}$ \\
& Xinqiao & $\mathrm{Cu}$ & $\mathrm{Au}, \mathrm{Mo}$ \\
& Magushan & $\mathrm{Cu}$ & $\mathrm{Au}$ \\
& Wushan & $\mathrm{Cu}, \mathrm{Zn}, \mathrm{Pb}$ & $\mathrm{Au}$ \\
& Chengmenshan & $\mathrm{Cu}, \mathrm{Mo}$ & \\
& Qixiashan & $\mathrm{Zn}, \mathrm{Pb}, \mathrm{Mn}$ & $\mathrm{Au}, \mathrm{Ag}, \mathrm{Cu}, \mathrm{Co}$ \\
& & & \\
\hline \multirow{4}{*}{ Dabaoshan } & $\mathrm{Cu}, \mathrm{W}, \mathrm{Zn}, \mathrm{Pb}$ & $\mathrm{Mo}, \mathrm{Bi}$ \\
& Yangliutang & $\mathrm{Zn}, \mathrm{Pb}$ & $\mathrm{Sb}$ \\
Fankou & $\mathrm{Zn}, \mathrm{Pb}$ & $\mathrm{Hg}, \mathrm{Ag}, \mathrm{Sb}$, \\
Nanling & Shiding & $\mathrm{Zn}, \mathrm{Pb}$ & $\mathrm{Ag}, \mathrm{U}$ \\
Hongyan & $\mathrm{Fe}(\mathrm{S})$ & $\mathrm{Tl}$ \\
Dajiangping & $\mathrm{Fe}(\mathrm{S})$ & $\mathrm{Tl}$ \\
Xiniu & $\mathrm{Fe}(\mathrm{S})$ & $\mathrm{Tl}$ \\
Dachang & $\mathrm{Sn}, \mathrm{Zn}, \mathrm{Pb}$ & $\mathrm{Sb}, \mathrm{Ag}, \mathrm{U}$ \\
\end{tabular}

Table 2 Comparison in fluid composition $\left(x 10^{-6)}\right.$ between massive sulphide deposits in the Lower Yangtze and Nanling Mountain regions.

\begin{tabular}{|c|c|c|c|c|c|c|}
\hline Region & Deposit & Mineral & $\begin{array}{l}\text { Sample } \\
\text { Number }\end{array}$ & $\mathbf{K}^{+}$ & $\mathrm{Na}^{+}$ & $\mathrm{K}^{+} / \mathrm{Na}^{+}$ \\
\hline \multirow{8}{*}{$\begin{array}{l}\text { Lower } \\
\text { Yangtze }\end{array}$} & \multirow[t]{3}{*}{ Tongguanshan } & n siderite & 3 & 7.13 & 16.4 & 0.43 \\
\hline & & pyrite & 1 & 0.51 & 2.00 & 0.26 \\
\hline & & quartz & 1 & 0.42 & 1.48 & 0.28 \\
\hline & \multirow[t]{2}{*}{ Qixiashan } & galena & 2 & 2.15 & 2.80 & 0.77 \\
\hline & & pyrite & 4 & 1.10 & 2.37 & 0.46 \\
\hline & Wushan & pyrite & 6 & 1.09 & 3.17 & 0.34 \\
\hline & Tongshan & siderite & & 7.50 & 17.6 & 0.43 \\
\hline & Magushan & siderite & & 3.40 & 6.80 & 0.50 \\
\hline \multirow{6}{*}{ Nanling } & Dabaoshan & pyrite & 3 & 2.30 & 1.80 & 1.28 \\
\hline & & sphalerite & & 2.84 & 0.10 & 28.4 \\
\hline & \multirow[t]{3}{*}{ Fankou } & galena & 2 & 1.80 & 1.70 & 1.06 \\
\hline & & sphalerite & 19 & 2.73 & 0.50 & 5.48 \\
\hline & & pyrite & 3 & 6.82 & 0.33 & 20.7 \\
\hline & Hongyan & pyrite & 3 & 0.38 & 0.29 & 1.31 \\
\hline
\end{tabular}

Data sources: Tongguanshan: This research and Wang (1987); Qixiashan: This research and East China Geoexploration Bureau (1990); Wushan: This research; Tongshan and Magushan: Wang (1987); Dabaoshan and Fankou: This research and Nin (1991). Hongyan: Institute of Geology, Metallurgical Ministry (1982).

mineral separates indicate that $91 \%$ of the mercury in the deposit is hosted in sphalerite, which has an average $\mathrm{Hg}$ content of $790 \mathrm{ppm}$. Most of the mercury is suggested to be scattered in the lattice of this mineral, althouth minute cinnabar grains $(<2 \mu \mathrm{m})$ have also been found in the ores of the deposit (Tu,1984; Huang, 1989).

Ores in the Dabaoshan mine of the Nanling Mountain region have an average of $0.04 \% \mathrm{Bi}$, but values up to $0.4 \% \mathrm{Bi}$ have been recorded. Bismuthinite has been found in the ores. Massive lead-zinc ores in the Fankou mine contain an average of $0.016 \% \mathrm{Sb}$. Stibnite crystals 1 to $2 \mathrm{~cm}$ in length have been found locally in the deposit. The powder-like pyrite ore in the Tianliao mine near Xiniu has an

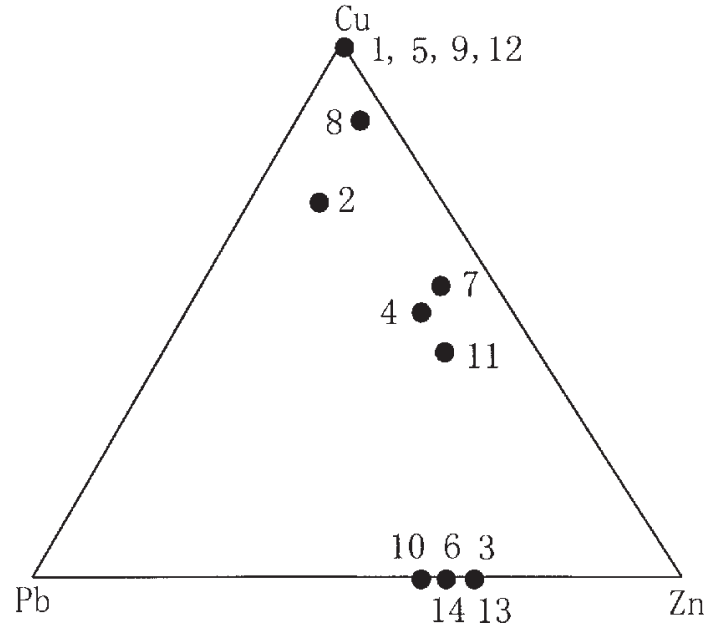

Figure $2 \mathrm{Cu}: \mathrm{Zn:Pb}$ ratios of massive sulphide deposits in South China. 1-Tongguanshan; 2-Xinqiao; 3-Fankou; 4-Magushan; 5-Longjiaoshan; 6-Qixiashan; 7-Linghou; 8-Dongxiang; 9-Yongping; 10-Lehua; 11-Dabaoshan. 12-Yangliutang; 13-Dongguashan; 14-Qibaoshan.

antimony content of $0.04 \%$. Ores from the Dachang tin mine of Guangxi Province and the Yangliutang lead-zinc deposit near Dabaoshan in North Guangdong also have remarkable concentrations of antimony. Pyrite ores from the Xiniu mine have recoverable thallium with an average concentration of $0.0019 \%$, and the average concentration in ore body No.5-1 reaches up to $0.0027 \%$. The thallium content is also high (up to $0.0046 \%$ ) in the sulphide ores at Dajiangping. Fifteen samples of pyrite separates from the Hongyan mine show an average of thallium content of $0.005 \%$ with a maximum of $0.015 \%$.

Several stratiform barite deposits with $\mathrm{n}$ to $10 \mathrm{n} \mathrm{Mt} \mathrm{BaSO}_{4}$ and tens of smaller ones are distributed in the Devonian sequence of the Nanling region ( $\mathrm{Li}$ and $\mathrm{Yu}, 1991$ ), although no significant barite accumulations have so far been reported in mining areas of the massive sulphides. Barite layers or lenses in these deposits are often accompanied by siliceous sediments, and contains various quantities of pyrite, sphalerite and galena, and occasionally chalcopyrite. Fracture-filling barite mineralizations with alterations of silicification, baritization, carbonatization and pyritization are found cutting the footwall rocks in some of the deposits ( $\mathrm{Li}$ and $\mathrm{Yu}, 1991$; Lei, 1998). $\delta^{34} S$ of barite and sulphide minerals varies in the ranges of $+10 \sim$ $+27 \%$ and $0.2 \sim+35 \%$, respectively. Homogenization temperatures of fluid inclusions within barite ranges from $105^{\circ} \mathrm{C}$ to $276^{\circ} \mathrm{C}$. These deposits have been recognized as products of Devonian submarine exhalation coeval with that for the massive sulphides in the same region ( $\mathrm{Li}$ and $\mathrm{Yu}, 1991$; Lei, 1998).

Tungsten and tin are also typical components of the massive sulphide ores in the Nanling Mountain region. The Dabaoshan mine has a $\mathrm{WO}_{3}$ reserve of 0.1 million tonnes at grades averaging $0.12 \%$. The stratiform pyrrhotite ores at Yindingge, Fujian Province, usually contain $0.02-0.1 \% \mathrm{~W}$. Scheelite is an important ore mineral in the Qianfeng mine of Fujian Province (Li, 1989). The Dongxiang and Yongping deposits in the Xinjiang basin, which is geographically situated between the Nanling Mountain and the Yangtze regions (Figure 1), contain averages of $0.11 \%$ and $0.13 \% \mathrm{WO}_{3}$, respectively, in their sulphide ores (Ren et al., 1993). The $\mathrm{WO}_{3}$ content of hematite ores at Dongxiang reaches $0.4-0.6 \%$ and has a positive correlation with the iron content of the ores.

The Dachang mine, Guangxi Province, is one of the largest polymetallic tin mines in the world with a total reserve of more than 1 million tons $\mathrm{Sn}$ and the richest ore averaging $0.71 \%$ Sn (Han et al., 1997; Fu et al., 1993; Jiang et al., 1999). Recent research has suggested that the deposit was originally a Devonian massive sulphide deposit (Zhou et al., 1987; Han and Hutchinson, 1989; Jiang et al., 1999). A considerable amount of tin in this deposit is also thought to 
LOWER YANGTZE
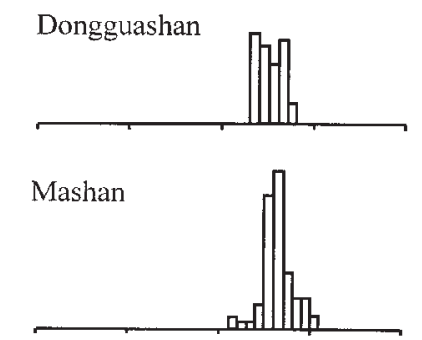

\section{Qixiashan}
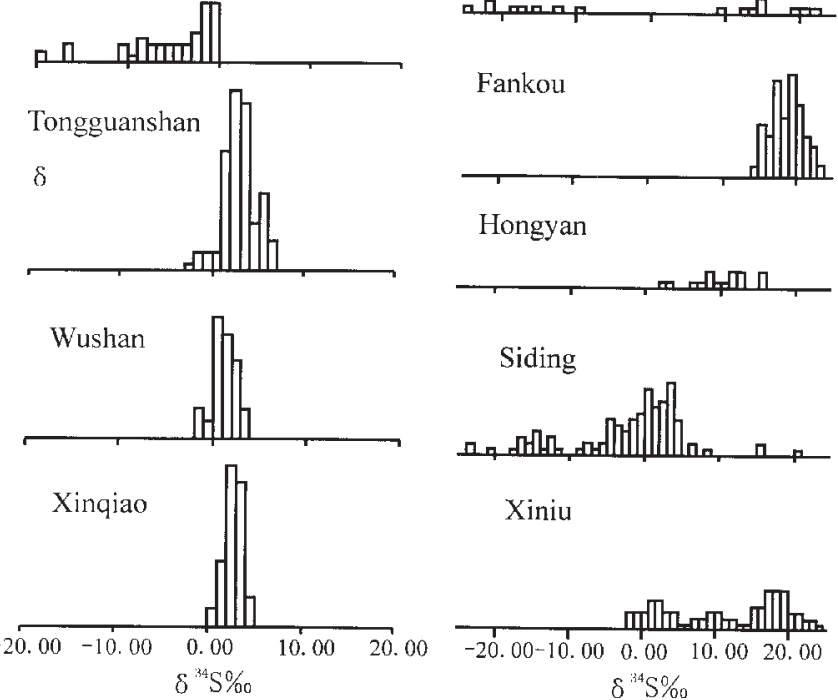

Xiniu

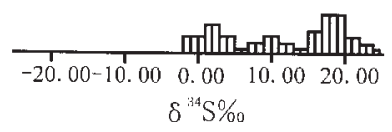

Figure 3 Histogram of $\delta{ }^{34} S \%$ of sulphides from massive sulphide deposits in the Lower Yangtze and the Nanling Mountain regions.

have been introduced by submarine exhalation (Han and Hutchinson, 1989; Zhang and Chai, 1987). Recently, we examined thin sections of the drill cores from the Changpo ore-zone at Dachang. Cassiterite grains $0.05-0.2 \mathrm{~mm}$ across have been found in a siliceous rock with intricate sedimentary layering. Cassiterite occurs only in one layer about $2 \mathrm{~mm}$ thick. The microcrystalline nature of the quartz grains of the host rock, which never exceed $0.02 \mathrm{~mm}$ across, appears unaffected by subsequent hydrothermal events. This observation indicates that the cassiterite in that layer should have been formed no later than diagenesis.

At the same stratigraphical levels as the massive sulphides in the Nanling Mountain region there are exhalative iron and manganese deposits, which are considered by the authors to be equivalents to the massive sulphides but to have been precipitated in more oxidising environments (Gu, 1987a). These deposits can also have high contents of tungsten and/or tin. For example, the iron-manganese ores in the Houjiangqiao mine of Hunan Province contain $450 \mathrm{ppm} \mathrm{WO}_{3}$ and $120 \mathrm{ppm}$ Sn. The tin content of iron-manganese ores from the Manaoshan mine, Hunan Province, averages 370 ppm (Tang, 1985). The iron ores at Makeng, Fujian Province was reported to contain $0.3-1.0 \% \mathrm{Sn}$ (Zhou, 1987). Interestingly, some of the Middle Devonian carbonate-hosted exhalative barite deposit also contain scheelite in their ore layers ( $\mathrm{Li}$ and $\mathrm{Yu}, 1991$ ).

Tungsten usually occurs as scheelite in sulphide ores and as wolframites in iron-oxide ores (Gu et al., 1993). In the Dongxiang, Yongping and Dabaoshan mines, scheelite occurs both as impregnations and in veinlets. Wolframites at Dongxiang can be identified by the naked eye as subhedral to euhedral grains less than $1 \mathrm{~mm}$ in size. Compositionally they are end members of the $\mathrm{FeWO}_{4}-\mathrm{MnWO}_{4}$ series with ferberite predominating and less hubnerite (Hua and $\mathrm{Hu}$, 1980).

\section{Isotope compositions}

Massive sulphide ores in the Lower Yangtze and the Nanling Mountain regions also differ in their sulphur and lead isotope compositions.

As indicated in Figure 3, the sulphur isotope compositions of sulphides in most deposits of the Lower Yangtze region are characterized by a tight distribution pattern. The $\delta^{34} \mathrm{~S}$ values have very limited variations with the histograms peak at several parts per thousand greater than zero (Gu and Xu, 1986; Gu et al., 1993). Such a distribution of sulphur isotopes could imply more or less homogenized, deep sources for sulphur in these deposits. The only exception is the Qixiashan lead-zinc deposit, which has pronounced negative $\delta^{34} \mathrm{~S}$ values, indicating significant involvement of biogenic sulphur. By contrast, the sulphides in the Nanling Mountain region show large variations in $\delta^{34} \mathrm{~S}$ values from very positive around $20 \%$, such as those at Fankou and Xiniu, to very negative between -10 and $-20 \%$, such as those at Dajiangping and Siding. Such a wide $\delta^{34} S$ distribution suggests that plenty of the sulphur in the Nanling Mountain deposits might have been produced via bacteriogenic reduction of seawater sulphate as is in the Irish $\mathrm{Zn}-\mathrm{Pb}$ deposits (Anderson et al., 1998). The positive $\delta^{34} \mathrm{~S}$ values around $20 \%$, which approach that of upper Palaeozoic seawater sulphate (Claypool et al., 1980), might indicate reduction in relatively closed systems (Ohmoto and Goldhober, 1997), whereas the negative values between -10 and $-20 \%$ o may represent reduction in relatively open systems (Ohmoto and Goldhober, 1997) with a $\mathrm{H}_{2} \mathrm{~S}_{-} \mathrm{SO}_{4}{ }^{2-}$ fractionation around -30 to -
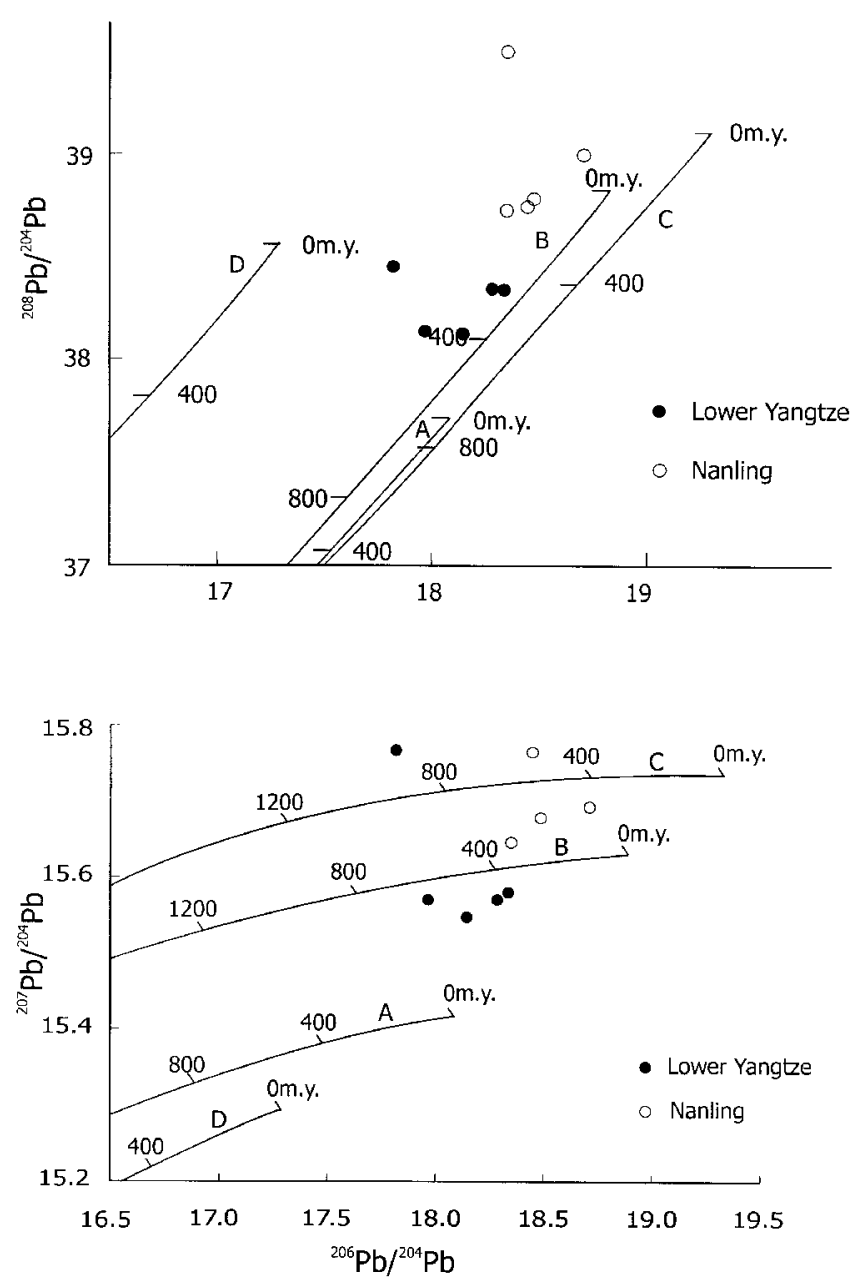

Figure 4 Plot of average ore lead isotopes for massive sulphide deposits in the Lower Yangtze and the Nanling Mountain districts. Growth curves: A-mantle; bB-orogen; $C$-upper crust; D-lower crust (after Doe et al., 1979). 


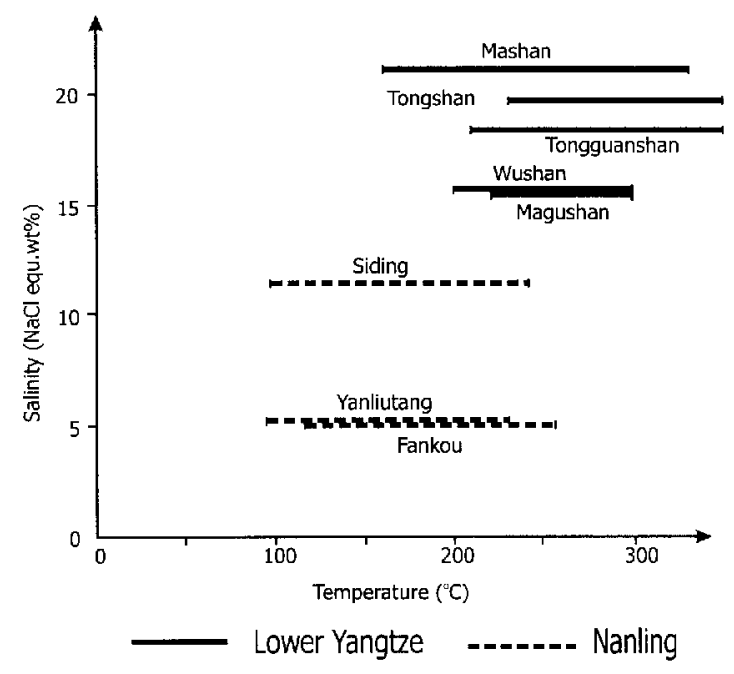

Figure 5 Comparison of ore-forming temperature $\left({ }^{\circ} \mathrm{C}\right)$ and fluid salinity (eqiv. wt\% $\mathrm{NaCl}$ ) between massive sulphide deposits in the Lower Yangtze and Nanling Mountain regions.

$45 \%$. The moderately positive $\delta^{34} \mathrm{~S}$ values between 0 and $+15 \%$ o may have been derived by reduction of seawater sulphate in the convection system. Experimental evidence indicates that sulphate can be reduced in high temperature hydrothermal systems by oxidation of $\mathrm{Fe}^{2+}$. This results in a fractionation between 0 and $25 \%$ lower than the starting sulphate, depending on the degree of reduction (Rhy and Ohmoto, 1974).

The lead isotope ratios of the sulphide ores from the Nanling Mountain region are more radiogenic than those of the lower Yangtze region. The Nanling samples are characterised by ${ }^{206} \mathrm{~Pb} /{ }^{204} \mathrm{~Pb}>18.34,{ }^{207} \mathrm{~Pb} /{ }^{204} \mathrm{~Pb}>15.64$ and ${ }^{208} \mathrm{~Pb} / 204 \mathrm{~Pb}>38.74$ (Figure 4). This highly radiogenic feature of the leads is comparable with those of the sediments in intracontinental basins elsewhere in the world (Doe and Zartman, 1979). Lead in the Nanling Mountain region is presumably ultimately derived from the basement rocks which sourced the metasedimentary package, though to date there are no isotopic analyses of the putative source rocks.

In the light of the fractionation between the ${ }^{238} \mathrm{U} /{ }^{204} \mathrm{~Pb}$ and the ${ }^{232} \mathrm{Th} / 204 \mathrm{~Pb}$ ratios during the evolution of continental crust (Doe and Zartman, 1979), the less radiogenic lead in the Lower Yangtze region, particularly the strong depletion of uranogenic with less depletion of thorogenic lead of the Qixiashan mine (Figure 4), may indicate that a significant portion of the lead in that region was derived from the Precambrian basement to the Palaeozoic basin or from a much deeper source in the continental crust. Thus it is not surprising that the single-stage model ages (Gu et al., 1993) are much older than the host strata of the ores.

If it were the case, as seems likely, that the leads in the ores were derived from various sources besides the mantle, the single-stage model ages may represent the youngest limit of their separation time from the U-Th- $\mathrm{Pb}$ system. It follows that the leads might have been separated from their radiogenic source earlier than is indicated by their model ages. If so, the concordant model ages as well as the older-than-mineralization ages $(\mathrm{Gu}$ et al., 1993) may be taken to imply that considerable proportions of the leads (normal and B-type leads) in both the Lower Yangtze and the Nanling Mountain regions were derived from the rocks beneath the Upper Palaeozoic sedimentary horizons that host the ores in the basins. In particular, the B-type ages of the Qixiashan mine
Table 3 Comparison of the features between massive sulphide deposits in the Lower Yangtze and the Nanling Mountain regions.

\begin{tabular}{lll}
\hline \multicolumn{1}{c}{ Region } & Lower Yangtze & \multicolumn{1}{c}{ Nanling } \\
\hline Ore-hosting strata & M. Carboniferous & Mainly M. \& U. Devonian \\
Basin basement & M. \& L. Precambrian & Caledonian \\
Crustal maturity & lower & higher \\
Major economic metals & $\mathrm{Cu}, \mathrm{Zn}, \mathrm{Pb}$ & $\mathrm{Zn}, \mathrm{Pb}, \mathrm{Cu}, \mathrm{Sn}$ \\
Associated metals & $\mathrm{Au}, \mathrm{Ag}, \mathrm{Co}, \mathrm{Mo}$ & $\mathrm{Ag}, \mathrm{Sb}, \mathrm{Hg}, \mathrm{W}, \mathrm{U}, \mathrm{Bi}, \mathrm{Tl}, \mathrm{Mo}$ \\
Ore-forming temperature & Higher & lower \\
Fluid salinity & Higher & lower \\
Fluid composition & sodium-rich & potassium-rich \\
$\delta^{34} \mathrm{~S} \%$ close to zero & close to zero, very positive or negative, \\
Sulphur source & from basement & from basement \pm bacteriogenic sulphur \\
Radiogenic lead & lower & higher \\
\hline
\end{tabular}

indicate a principal source region deep in the Precambrian basement. The J-type lead which gives younger-than-mineralization ages $(\mathrm{Gu}$ et al., 1993) might have been transferred to the ores either during the sedimentary/diagenetic processes or by post-diagenetic fluids from more radiogenic sources.

\section{Fluid features}

Analyses of fluid inclusions in sulphides and other associated minerals (Table 2 and Figure 5) show a low $\mathrm{K}^{+} / \mathrm{Na}^{+}$ratio $(<1)$ but higher temperature and salinity for the samples from the Lower Yangtze region than those from the Nanling region $\left(\mathrm{K}^{+} / \mathrm{Na}^{+}>1\right)$. Although fluid inclusions could have been formed during diagenesis and hence may not indicate the exact physico-chemical parameters of either the ascending sub-seafloor fluids or the submarine brines, it may still reflect the differences of fluid property and ore-forming environment in the two regions. The potassium-rich nature of inclusion fluids in the Nanling Mountain region is reminiscent of those from the modern sulphide deposit in the Okinawa Trough, which were interpreted by Urabe and Marumo (1991) to have been formed by the reaction of the fluids with underlying potassium-rich volcanic rocks.

The higher $\mathrm{K}^{+}$contents in fluid inclusions of the Nanling Mountain region are consistent with the chemistry of the orebodies at least in one case. For example, Han and Hutchinson (1989) reported a thin layer of orthoclase as an exhalative product in the tinbearing massive sulphide deposit at Dachang, Guangxi Province.

Table 3 presents a general comparison of the features for massive sulphide deposits between the Lower Yangtze and the Nanling Mountain regions.

\section{Crustal maturity of the two regions}

We have demonstrated above that contrasts exist in ore metals, isotope compositions, ore-forming temperatures and fluid properties between the Upper Palaeozoic massive sulphide deposits of the Yangtze and the Nanling Mountain regions. These contrasts can be well elucidated in terms of variations in maturity of the continental crust upon which deposits of these two regions were formed, although the Nanling deposits show a stronger bacteria activity during their formation.

Crustal maturity is defined by He and co-workers (1989) as the extent to which the crust approaches its final product-stable continental crust during its course of formation and evolution.

The deformed and metamorphosed basements underlying the sedimentary basins in which the massive sulphide ores in the Lower Yangtze and the Nanling Mountain regions were formed comprise the Proterozoic and the Caledonian successions, respectively. Geological features of the basements show that these two regions were different in crustal maturity during the Upper Palaeozoic time. 

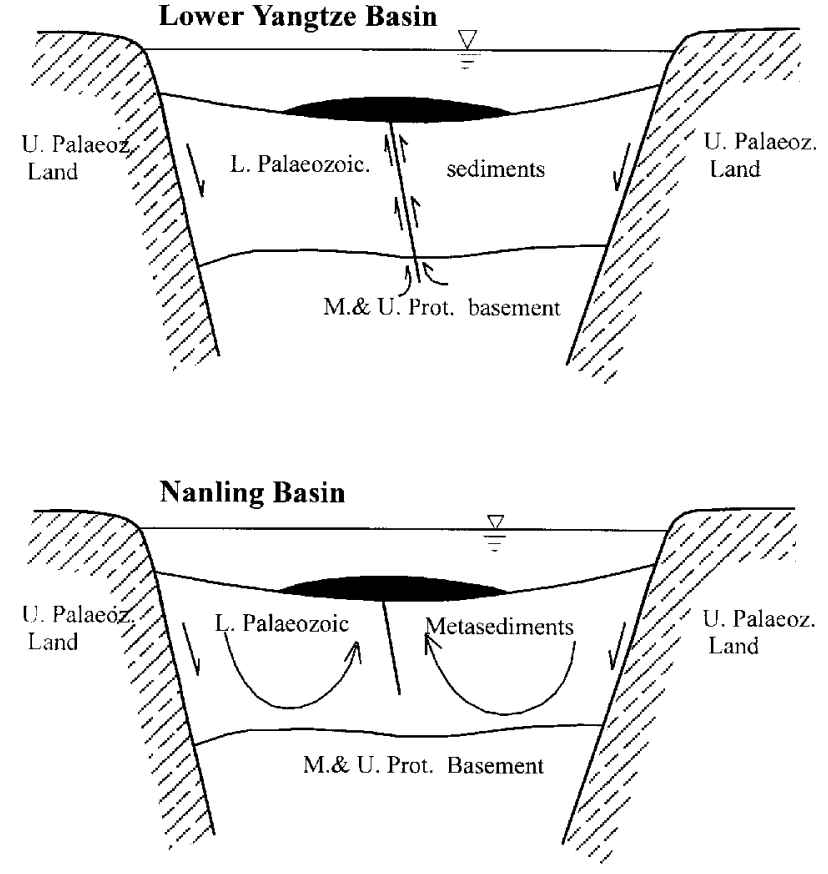

Figure 6 Contrasting genetic models for the Lower Yangtze (upper) and the Nanling Mountain (lower) basins.

An essential indication of crustal maturity is given by the characteristics of igneous activity, especially by the $\mathrm{K}_{2} \mathrm{O} /\left(\mathrm{CaO}+\mathrm{Na}_{2} \mathrm{O}\right)$ ratios of intrusive rocks (Brown et al., 1984; He et al., 1989). The basement for the Lower-Upper Palaeozoic ore-hosting marine basin of the Lower Yangtze region is composed of a succession of Middle and Late Proterozoic eugeosynclinal flysch with significant amount of spilitic-keratophyric volcanic rocks. These basement rocks crop out in the Zhangbaling area to the north of the Lower Yangtze basin and are thought to have been formed in a back-arc environment (Guo et al., 1980). Some Late Proterozoic intrusives have also been found in the Feidong area, which are dioritic and quartz dioritic in composition (Chang et al., 1991). All these igneous rocks are characterized by $\mathrm{K}_{2} \mathrm{O} / \mathrm{Na}_{2} \mathrm{O}<1$. No Caledonian granitic intrusions have been found in the Lower Yangtze region. These features can be regarded as evidence of lower maturity of the continental crust beneath the Upper Palaeozoic Lower Yangtze basin. In contrast, the Caledonian geosynclinal successions of the Nanling Mountain region are composed of greywackes, flysches and flyschoids with a total thickness of more than $10 \mathrm{~km}$. Only insignificant occurrences of volcanic intercalations have been reported in this region (DGNU, 1981). Of these, the andesites, dacites and rhyolites at Mashan in the Guangdong Province have $\mathrm{K}_{2} \mathrm{O} / \mathrm{Na}_{2} \mathrm{O}>1$ (Yang, 1987). Caledonian deformation, metamorphism, migmatization and granite intrusion are widespread in the Nanling Mountain region. Late Caledonian granites have average contents of $\mathrm{K}_{2} \mathrm{O}$ and $\mathrm{Na}_{2} \mathrm{O}$ totaling $7.10 \mathrm{wt} \%$, and an average $\mathrm{K}_{2} \mathrm{O} / \mathrm{Na}_{2} \mathrm{O}$ ratio of 1.5 . Together they comprise a suite evolving towards two-mica granites (DGNU, 1981). These features suggest that the Caledonian basement underlying the Upper Palaeozoic basins of the Nanling Mountain region had higher maturity than that beneath the Lower Yangtze region. He et al., (1989) suggested that the present crustal thickness is also an indicator of crustal maturity. The present crust thickness in the Nanling Mountain region is 34-37 km (Guo et al., 1982; Huang, 1992), whereas in the Lower Yangtze region it is only about $25 \mathrm{~km}$ (Yun et al., 1983). Based on the fact that these two regions have similar geological histories since Upper Palaeozoic time, we suggest that the crustal thickness and hence crustal maturity in the Nanling Mountain region was greater than those in the Lower Yangtze region during the development of the ore-forming Upper Palaeozoic basins.
Although no systematic data are available on trace element abundances of the two crustal segments, preliminary research revealed a higher uranium content of the upper crust in the Nanling Mountain region than that in the Lower Yangtze region (Zhang et al., 1993). This would also imply a higher crustal maturity in the Nanling Mountain region and is comparable with the trace element model proposed by Brown and co-workers (1984).

$\mathrm{Xu}$ and his colleagues (1982) classified the Mesozoic granites in South China into the syntexis- and the transformation-types, which are loose equivalents to the I- and S-types of Chappell and White (1974). Large numbers of granite bodies of the Lower Yangtze and the Nanling Mountain regions are typical I- and Stypes, respectively, implying that these two regions might have inherited and even intensified their Upper Palaeozoic differences in crustal maturity during the Mesozoic time.

\section{Discussion and conclusions}

According to the contrasting metal and isotope compositions and fluid features of the ores in the two regions, we would suggest that they may have different metal-fluid sources and genetic models. A considerable amount of the ore metals and fluids in the massive sulphide deposits of the Lower Yangtze region could have been derived from the Precambrian basement. The ore-forming fluids were driven up along deep faults to the seafloor without significant contamination from cool and low-salinity sea water during their ascent (Figure 6). In contrast, metals and sulphur in the massive sulphides of the Nanling Mountain region could have been leached mostly from the Caledonian basement. The ore-forming fluids may largely originate from geothermally driven convecting sea-water of low temperature and salinity (Figure 6). Recent research (Lewis et al., 1995; Russell et al., 1995) has suggested that hydrothermal convection is a process that may readily occur throughout the upper crust in which cells form with or without specific structural control. A calculation (cf. Russell, 1968) has been made to estimate the volume of the source rocks in the Caledonian basement that supposedly supplied metals during leaching for the 1.7 Mt Pb and 3.4 Mt $\mathrm{Zn}$ of the Fankou deposit. Based on the average concentrations of $20 \mathrm{ppm} \mathrm{Pb}$ and 90 ppm $\mathrm{Zn}$ for the basement of the Nanling region (Yu et al., 1987), and assuming that the basement rocks had special gravity of $2.6 \mathrm{~g} / \mathrm{cm} 3$ and that $10 \%$ of the lead was leached from the source, the result shows that a source volume of some $320 \mathrm{~km}^{3}$ should have been involved in the convection cell. Further calculation suggests that $4.4 \%$ of the zinc might have been leached from the same source for the formation of the ore in that deposit.

As basement composition is an essential indication for crustal maturity, we will able to establish the connections between the features of massive sulphides and the maturity of the continental crust during ore formation, and thereby account for the compositional contrasts of the ores between these two regions:

Copper, gold and cobalt appear to have higher concentrations in more mafic rocks (Graf, 1977; Hutchinson, 1990), and hence, these metals are enriched in lower-maturity crust such as in the Lower Yangtze region. The Precambrian chlorite schists of the Pichen group, which is locally exposed about $70 \mathrm{~km}$ east to Nanjing and is thought to represent the basement under the Lower Yangtze Palaeozoic basin, have average contents of $106 \mathrm{ppm} \mathrm{Cu}$ and $6.2 \mathrm{ppb}$ gold (Li et al., 1997). Based on the analyses of residual enclaves of Precambrian amphibolites and schists inside a granite body at Tongling, Du (1999) suggested that the basement metamorphic rocks have an average content of $373 \mathrm{ppm} \mathrm{Cu}$. Therefore, the basement rocks of the Lower Yangtze region were likely sources of these metals and sulphur.

By contrast, lead, zinc, silver, uranium, bismuth, antimony, mercury, fluorine and boron are relatively enriched in more felsic rocks (Hutchinson, 1990; Liu et al., 1984) and hence in the highermaturity crust such as in the Nanling Mountain region. The Lower Cambrian carbonaceous sediments in South China commonly have 
anomalously high uranium contents up to several ppm (Zhang et al., 1993). Yu et al., (1987) have reported that the average bismuth contents in the Sinian, Cambrian and Ordovician strata in the Nanling Mountain region are 2.2, 1.9 and 2.9 times, respectively, the values given by Taylor (1964) for the continental crust. The Sinian, Cambrian and Ordovician-Silurian sediments in central Hunan Province have average antimony contents of 214, 72 and $23 \mathrm{ppm}$, respectively (Tu et al., 1984). Mercury contents of the Cambrian sediments are generally higher than $0.2 \mathrm{ppm}$ in the Wanshan area of East Guizhou Province (Tu et al., 1984).

The hydrothermal convection through the potassium-rich Caledonian basement in the Nanling Mountain region produced oreforming fluids with higher potassium content than those in the Lower Yangtze region (Table 5). Thallium and barium, like lead, have similar geochemical features to potassium, therefore they tend to enter the lattice of $\mathrm{K}$-feldspar. As a result, thallium and barium are also apparently enriched in the matured crust that has high potassium content. This is in accord with the high thallium contents of the sulphide ores and the widespread exhalative barite deposits in the Nanling Mountain region. The large influx of seawater into the subseafloor convecting systems of the Nanling Mountain region resulted in high concentrations of sulphate sulphur and lower temperature $\left(<250^{\circ} \mathrm{C}\right)$ and salinity of the circulating fluids, as is suggested from the isotope and fluid inclusion data of their ores. Bacteria are likely to have played an important role in the reduction of seawater sulphate and, to some extent, in the fixation of some metals. The close association of silver, uranium, antimony and mercury with lead and zinc can be accounted for not only by their higher abundances in sedimentary successions of the Caledonian basement, but also by their relatively higher stability in medium to low temperature ore-forming fluids in the Nanling Mountain region.

Tungsten and tin are two characteristic elements enriched in the continental crust in South China (Gu et al., 1990, 1992; Hutchison and Chakraborty, 1979). It was reported that some argillaceous and clastic horizons of the Lower Palaeozoic successions in the basement of this region have primary enrichment of 50-500 ppm tungsten (Liu and Ma, 1987) and 10-40 ppm tin (Xian, 1984). Consequently, it is not surprising that these two metals are strongly enriched in the massive sulphide deposits associated with matured continental crust such as in the Nanling Mountain region. The higher contents of radiogenic lead in the Nanling Mountain massive sulphide deposits are consistent with the common knowledge that matured continental crust is usually higher in radiogenic lead (Doe and Zartman, 1979).

In addition to sub-seafloor leaching by the convecting fluids of terrigenous sediments fed from the surrounding post-Caledonian lands, the characteristic elements of the continental crust could have been transported to the massive sulphide ore bodies by later-stage magmatism and relevant hydrothermal activities (cf. Gu et al., 1993). Many of the Upper Palaeozoic massive sulphide layers were intruded by Mesozoic granites of the syntexis-type in the Lower Yangtze region and the transformation-type in the Nanling Mountain region (Xu et al., 1982; Gu, 1987b, Zhou et al., 1987). Since the localisation of the massive sulphides and the granites were controlled by the same regional faults, the magmas are thought to have intruded through the same tectonic pathways as the earlier subseafloor hydrothermal systems. Crustal materials could have been involved in Mesozoic magmas during partial melting or assimilation and then superimposed on to the massive sulphide layers during post-magmatic processes (Gu et al., 1993). Magmatic hydrothermal mineralisations on the contact zones between granites and the Upper Palaeozoic ore layers are dominated by copper in the Lower Yangtze region, such as those at Wushan, Tongguanshan and Dongguashan (Gu, 1984; Gu et al., 1993), but in the Nanling region the magmatic hydrothermal mineralizations are characterized by tungsten and tin, such as those at Dabaoshan and Dachang (Liu and Zhou, 1985; Han et al., 1997; Lei, 1998). These overprinted mineralisations have resulted in the intensification of the compositional contrasts between massive sulphide ores of the two regions.

\section{Acknowledgements}

This research was financially supported by the Natural Science Foundation of China (Project Nos. 49773194 and 49733120). We thank the many exploration companies who helped the authors to access the deposits and to obtain the rock and ore samples. Many thanks are also given to Professors M. Russell and Shao-Yong Jiang for their constructive comments and language corrections which improved the manuscript significantly.

\section{References}

Anderson, I. K., Ashton, J. H., Boyce, A. J., Fallick, A. E. and Russell, M.J., 1998, Ore depositional processes in the Navan $\mathrm{Zn}-\mathrm{Pb}$ deposit, Ireland: Econ. Geol., v.93, pp.535-563.

Brown, G. C., Thorpe, R. S., and Webb, P. C., 1984, The geochemical characteristics of granites in contrasting arcs and comments on magma sources: J. Geol. Soc. London, v. 141, pp.413-426.

Chang, Y.-F., Liu, X.-P., and Wu, Y.-Ch., 1991, The Copper-Iron Belt of the Lower and Middle Reaches of the Changjiang River (in Chinese with an English abstract): Geological Publishing House, Beijing, pp.1-379.

Chappell, B. W., and White, A. J. R., 1974, Two contrasting granite types: Pacific Geology, v. 8: pp.173-174.

Claypool, D.E., Mullins, H. T., Sakai, I.R. and Zak, I., 1980, the age curves for sulfur and oxygen isotopes in marine sulfate and their mutual interpretation: Chemical Geology, v.28: pp.199-260.

DGNU (Department of Geology, Nanjing University), 1981, Granites of South China and Their Metallogenic Relations (in Chinese): Science Press, Beijing, pp.1-395.

Doe, B. R. and Zartman, R. E., Plumbotectonics, 1979, Plumbotectonics, the Phanerozoic, in Barnes, H. L., ed., Geochemistry of Hydrothermal Ore Deposits: New York, John Wiley \& Sons, second edition, pp.22-79.

Du Yangsong, 1999, Petrological and mineralogical study of enclaves in plutons in the typical mining districts of Tongling, Anhui and its bearing on the process of magmatism-metallogeny: Chinese Journal of Geochemistry, 18(3), pp.208-218.

Fouquet, Y., Stackelberg, U. V., Charlou, J. L., Erzinger, J., and Herzig, P. M., 1993, Metallogenesis in back-arc environmnets: the Lau basin example: Econ. Geol., v.88, pp2154-2181.

Fu, M., Kwak, T.A.P., and Mernach, T.P., 1993, Fluid inclusion studies of zoning in the Dachang tin-polymetallic ore field, People's Republic of China: Econ. Geol., v.88, pp.283-300

Fu, S.-G., 1977, Geology of the pyrite-type copper deposits in the Lower Yangtze belt (in Chinese): Journal of Nanjing University (Natural Sciences Edition), v.13, n.4, pp.43-67.

Graf, J. L., 1977, Rare earth elements as hydrothermal tracers during the formation of massive sulphide deposits in volcanic rocks: Econ. Geol., v.72, pp.527-548.

Gu Lianxing, 1984, Metal Zonations of the South China-type massive sulphide and related deposits (in Chinese with an English abstract): Journal of Nanjing University (Geology Edition), n..4, pp.57-71.

$\mathrm{Gu}, \mathrm{L}-\mathrm{X}$., 1987a, Genetic relationship between stratiform manganese ores and lead-zinc veinlets in the Lehua mine, Jiangxi Province (in Chinese with an English abstract): Geological Review, v.33, n.2, pp.267-274.

Gu, L-X., 1987b, The Mesozoic intrusives associated with the Carboniferous massive sulphide ore deposit in Wushan, Jiangxi Province (in Chinese with an English abstract): Acta Petrologica Sinica, n.1, pp.64-76.

Gu, L-X., Hu, W.-X., He, J.-X., and Xu, Y.-T., 1993, Geology and Genesis of the Upper Palaeozoic Massive sulphide deposits in South China: Transactions of the Institution of Mining and Metallurgy. Section B, Applied earth science, May-August, pp.83-96.

Gu, L-X. and Xu, K.-Q., 1984, The Middle Carboniferous marine volcanics and the origin of the bedded ore in Wushan, Jiangxi Province (in Chinese with an English abstract): Journal of the Guilin College of Geology, v.4, n. 4 , pp91-102.

$\mathrm{Gu}, \mathrm{L}-\mathrm{X}$. and $\mathrm{Xu}, \mathrm{K} . \mathrm{-Q} ., 1986$, On the Mid-Carboniferous submarine massive sulphide deposits in the lower reaches of the Changjiang (Yangtze) River (in Chinese with an English abstract): Acta Geologica Sinica, v.60, n.2, pp.176-188.

Gu, L-X.. and Xu K.-Q., 1987, The tectonic development and related metallogenesis of the Lower Yangtze fault depression belt (in Chinese with an English abstract): Journal of Guilin College of Geology, v.7, n.4, pp.253251 . 
Gu, L-X., and Yang, H., 1989, Footwall mineralization of the South ChinaType massive sulphide deposits (in Chinese with an English abstract): Geological Review, n.4, pp.308-313.

Gu, L-X., Yang, H., Zheng, S.-J., and Liao J.-J., 1990, Tungsten and tin-two characteristic elements of the South China-type massive sulphide deposits (in Chinese with an English abstract): Geological Review, v.35, n.4, pp.298-304.

Gu, L-X., Yang, H., Zheng, S.-J., and Liao, J.-J., 1992, Tungsten enrichment in the South China-type massive sulphide and associated deposits: Chinese Journal of Geochemistry, v.11, n.4, pp.344-351.

Gu, L-X., Zheng, S.-J., 1990, Melnikovite in the South China-type massive sulphide deposits and its annealing (in Chinese with an English abstract): Acta Petrologica et Mineralogica, v.9, n.4, pp.351-356.

Guo, L.-Z, Shi, Y.-S., and Ma, R.-S., 1980, The geotectonic framework and crustal evolution of South China (in Chinese with an English abstract). in Scientific Paper on Geology for International Exchange, prepared for the 26th international geological congress: Geological Publishing House, Beijing, v.1, pp.109-116.

Guo, L.-Z., Yu, J.-H., Shi, Y.-S., Ma, R.-S., and Lu, H.-F., 1982, On the time and space distribution of the granitic rocks and their relations to tectonic configuration and crustal evolution in southeawtern China, in Xu Keqin and Tu Guangchi, eds, Geology of Granites and Their Metallogenetic Relations: Jiangsu Science and Technology Press, Nanjing, pp.55-63.

Han, F., and Hutchinson, R. W., 1989, Evidence for exhalative origin for rocks and ores of the Dachang tin-polymetallic field: the ore-bearing formation and hydrothermal exhalative sedimentary rocks (in Chinese with an English abstract): Mineral Deposits, v.8, n.2, pp.40-48.

Han, F., Zhao, R.-S., Shen, J.-Z., Hutchinson, R.W., Jiang, S.-Y., and Chen H.-D., 1997, Geology and Origin of Ores in the Dachang Tin-Polymetallic Ore Field (in Chinese with an English abstract): Geological Publishing House, Beijing, pp.1-213.

He, G.-Q., Han, B.-F., Li, M.-S., 1989, On the crustal maturity and its applications to geotectonic research (in Chinese with an English abstract), in Qian Xianglin, ed., Geosciences of the Lithosphere: Peking University Press, Beijing, pp.36-42.

Hsu, K.-Ch., Chu, K.-Ts, and Ren, Ch.-K, 1980, On the origin of some iron and copper deposits in several marine fault depressions of Southeastern China (in Chinese), in Scientific Papers on Geology for International Exchange, Prepared for the 26th International Geological Congress, Part 3, Metallogenesis and Mineral Ores: Beijing: Geological Publishing House, Beijing, pp.49-58.

Hu Wenxuan, Gu, L-X., Xu K.-Q., and Hu, S.-X., 1994, Metallogenic regularities and prospecting direction of massive sulphide deposits in South China (in Chinese with an English abstract): Geological Review, v.40, n.6, pp.513-519.

Hua, Y.-R., and Hu, Z.-G.,. 1980, Genesis of the Fenglin Tungsten-Copper deposit (in Chinese): Geology and Prospecting, n.11, pp.8-14.

Huang, H.-L., 1989, Mercury in the lead-zinc ores of the Fankou mine, Guangdong Province and its extractability (in Chinese): Proceedings of the 4th conference on mineral deposits of China: v.2, pp.86-87.

Huang, S.-P, 1992, Variations of heat flow and crustal thickness in the continental areas of China (in Chinese with an English abstract): Acta Geophysica Sinica, v.35, n.4, pp.441-450

Hutchinson, R. W., 1980, Massive base metal sulphide deposits as guides to tectonic evolution, in Strangway, D. W., ed., The Continental Crust and Its Mineral Deposits: Geol Assoc Can Spec Pap 20, pp.659-684.

Hutchinson, R. W., 1990, Precious metals in massive base metal sulphide deposits: Geologische Rundschau. Band 79, Heft 2, pp.241-263.

Hutchison, C. S. and Chakraborty, K. R., 1979, Tin: a mantle or crustal source?: Geol. Soc. Malaysia Bull., v.11: pp.71-79.

Ishihara, S. and Terashima, S., 1974, Base metal contents of the basement rocks of Kuroko deposits - an overall view to examine their effect on the Kuroko mineralization: Soc. Mining geologists Japan, spec. Issue 6, pp.421-430.

Jiang, S.-Y., Han, F., Shen, J.-Z., and Palmer, M. R., 1999, Chemical and Rb$\mathrm{Sr}, \mathrm{Sm}-\mathrm{Nb}$ isotopic systematics of tourmaline from the Dachang Sn-polymetallic ore deposit, Guangxi Province, P.R. China: Chemical Geology, v.157, pp.49-67.

Lei, L.-Q., 1998, The Minerogenetic Mechanism in the Dachang Superlarge Tin-Polymetallic Ore Deposit, Guangxi (in Chinese with an English abstract): Guangxi Normal university Press, Xining, pp.1-94.

Lewis, H., Couples, G.D. and Russell, M.J., 1995, Characterization of fluidflow systems for Irish lead-zinc deposits-contributions from mass balance: Trans. Instn Min. Metall. (Sect. B: Appl. earth sci.), section B, 104, May-August, pp.145-155.

Li, X.-H., 1997, Timing of the Cathaysia Block formation: constraints from SHRIMP U-Pb zircon geochronology: Episodes, 20(3): 187-192.
Li, Y.-H., 1989, A preliminary discussion on the genesis of polymetallic sulphide ore deposit in Qianfeng, Datian County of Fujian ( in Chinese with an English abstract): Geology of Fujian, n.2, pp.129-140.

Li, W.-Y., and Yu, H.-Y., 1991, Barite Deposits in China (in Chinese): Geological Publishing House. Beijing, pp.1-105.

Li W.-D., Wang W.-B., Fan H.-Y., and D.-P., 1997, The conditions to form copper (gold) ore deposit concentrated areas and the possibilities to discover supergigantic copper (gold) ore deposit in Middle-Lower Yangtze area (in Chinese with an English abstract): Volcanology \& Mineral Resources, supplementary issure, n.20, 1-131.

Liu, X.-S and Zhou, S.-Z., 1985, On the Occurrence of Middle Devonian volcanics and analysis of ore-forming mechanism of siderite polymetallic ore deposit from Dabaoshan, Qujiang County, Guandong Province (in Chinese with an English abstract): Journal of Nanjing University (Natural Sciences Edition). v. 21, pp.348-360.

Liu, Y.-J., and Ma, D.-S., 1987, Geochemistry of tungsten (in Chinese): Science Press, Beijing, pp.1-232.

Liu, Y.-J., Cao, L.-M., and Li, Z.-L., 1984, Elemental Geochemistry (in Chinese): Science Press, Beijing, pp.1-548.

Ma, K.-Y., and Sun, D.-M., 1985, The extension and structual evolution of the Huaxia shield (in Chinese with an English abstract): Bulletin of the Institute of Mineral Deposits, Chinese Academy of Geological Sciences, n.2, pp.125-132

Ohmoto, H., and Goldhaber, M. B., 1997, Sulfur and Carbon isotopes. in H.T. Barnes (ed.), Geochemistry of Hydrothermal Ore Deposits: John Willey \& Sons, Inc., pp.517-612.

Ren J.-G., 1993, A new understanding of the genesis of the Yongping ore deposit, Jiangxi (in Chinese with English abstract): Kuangshan Dizhi (Mining Geology), v.14, n.2: pp.93-98

Russell, M.J., 1968, Structural controls of base metal mineralization in Ireland in relation to continental drift: Transactions of the Institution of Mining and Metallurgy, Section B, pp.117-128.

Russell, M.J., Couples, G.D. and Lewis, H., 1995, SEDEX genesis and superdeep boreholes: Can hydrostatic pore pressures exist down to the brittleductile boundary? in Pasava, Kribek and Zak (eds.), Mineral Deposits: Balkema Rotterdam, pp.315-318.

Rye, O.R., and Ohmoto, H., 1974, Sulphur and carbon isotopes and ore genesis: a review: Econ. Geol., 69: pp.826-842.

Sawkins, F. J., 1976, Massive sulphide deposits in relation to geotectonics, in D. F. Strong (ed.), Metallogeny and Plate Tectonics: Geol. Assoc. Canada Spec. Publ., v.14, pp.221-242.

Shi, Y.-S., Sheng, X.-Z., Ma, R.-S., and Zuo, G.-C. 1963, On the inheritance and superimposition of tectonic basins (in Chinese): Journal of Nanjing University (geology edition), n.3, pp.32-40.

Shui, T., 1987, Basement tectonics of the continent in Southeast China (in Chinese): Scientia Sinica (Science in China), Series B, n.4, pp.414-422.

Tang, G.-Q., 1985, Geology and genesis of the iron-manganese polymetallic deposit at Manaoshan, Hunan Province (in Chinese), in Department of Regional and Economic Geology, Ministry of Geology and Mineral Resources, ed., Collections of Papers on Manganese deposits in China: Geological Publishing House, Beijing, pp.174-177.

Taylor, S. R., 1964, The abundance of chemical elements in the continental crust-a new table: Geochim. Cosmochim. Acta, v.28, pp.1273-1285.

Tu G.-C. , 1984, Geochemistry of Stratabound Ore Deposits of China (in Chinese): Science Press, Beijing, v.1, pp.1- 54.

Urabe, T. and Marumo, K., 1991, A new model for kuroko-type deposits of Japan: Episodes, v.14, n.3, pp.246-251.

Wang, W.-B., Ji, S.-X., Xing, W.-C., and Zhou, H.-M., 1986, Cu-bearing pyrite deposits in the Jiu-Rui region, Jiangxi Province: Their geological Characteristics and genesis (in Chinese with an English abstract). Bull. Nanjing Inst. Geol. Miner. Res., Chinese Acad. Geol. Sci, n.7, no.2, pp.26-43.

Xian, B.-Q., 1984, A discussion on the ore-forming conditions and distributional regularity of the tin ore deposits of Guangxi (in Chinese with an English abstract): Acta Geologica Sinica, v.58, n.1, pp.49-62.

Xu K.-Q., Sun, N., Wang D.-Z., Liu, Y.-J., Hu, S.-X., and Ji, S.-Y., 1982, Petrology of granites and their metallogenetic relations in South China, in $\mathrm{Xu}$ Keqin and Tu Guangchi, eds., Geology of Granites and their metallogenetic relations: Science Press, Beijing, pp.1-32.

$\mathrm{Xu}$, K.-Q., and Zhu, J.-C., 1978, Origin of the sedimentary- (or volcanosedimentary-) iron-copper deposits in some fault depression belts in Southeast China (in Chinese): Fujian Geology. n.4, pp.1-68.

Yang, S.-F., 1987, The paired granite belts and plate tectonics (in Chinese): Science Press, Beijing, pp.1-98.

Yu, C.-W., Luo, T.-C., and Bao, Z.-Y., 1987, Regional Geochemistry of the Nanling District (in Chinese with an English abstract): Geological Publishing House, Beijing, pp.1-543. 
Yue, W.-Z, Ye, Z.-Z, Wei, N.-Y., Jiang, Y.-H., and Ji. S.-X., 1993, Sedimentary Geology and Stratabound Massive Sulphide Deposits of Late Carboniferous Weining Age in the Middle and Lower Yangtze Reaches (in Chinese with an English abstract): Geological Publishing House. Beijing, pp.1-163.

Yun, L.-L., Ding, Y.-W., Jiang, Y.-J., Wang, S.-L., 1983, Analysis of the data from the seismic explosions at Yongping in Jiangxi Province and some interpretations of deep structures in South China (in Chinese): Journal of Earthquake Studies, n.6, pp.28-33.

Zhang, B.-T., and Zhang, Z.-H., 1993, The Evolution of Continental Crust and Uranium Metallization in Southeastern China (In Chinese): Atomic Energy Press, Beijing, pp.1-208.

Zhang, G.-L., and Chai, H.-Y., 1987, Genesis of the Dachang tin polymetallic deposit, Guangxi (in Chinese with an English abstract): Geological Review, v.33, n.5, pp.426-436.

Zhang, Z.-H., 1991, A discussion on some problems about the evolution of continental crust in the eastern part of South China (in Chinese with an English abstract): Journal of Nanjing University (Earth Sciences), v.3, n.2, pp.103-110.

Zhou, H.-Y., Xu, K.-Q., Ye, J., and Chen, Z.-Q., 1987, Geological Features and ore forming mechanism of the Dachang strata-bound cassiterite-sulphide polymetallic deposit, Guangxi (in Chinese with an English abstract): Journal of Nanjing University (Natural sciences edition), v.23, n.3, pp.534-544.

Zhu, J.-C., and Zhang, C.-H., 1981, On the occurrence of Carboniferous volcanics and origin of the copper and tungsten deposits of the Fenlin district, Dongxiang, Jiangxi (in Chinese with an English abstract): Journal of Nanjing University (Natural Sciences Edition), v.17, n.2, pp.269-282.

Lian-Xing $\boldsymbol{G u}$ is Professor of Department of Earth Sciences, Nanjing University, Nanjing, China. He received his B.S. degree from Peking University (1967) and his Ph.D. from Nanjing University (1985). His main research interests are massive sulphide deposits, and granites and related mineralizations. His current projects include studies of the oreforming fluids from massive sulphide deposits in SE China, tectonic evolution of the Bogda orogenic belt of NW China, and retrogressive fluids of the eclogite area in the Dabie region.
Wen-Xuan Hu is Associate Professor of Department of Earth Sciences, Nanjing University, China. He obtained degrees of B.Sc. from the Shandong Mining Institute, China in 1982 and M.Sc. and Ph.D. from China University of Geosciences, Beijing in 1985 and 1988 respectively. From 1988 to 1990 he was a post-doctoral research assistant in the mineral deposit division of Department of Earth Sciences, Nanjing University. His ongoing projects include studies of fluids for gold mineralisations and geochemistry of petroleum reservoirs.

Jin-Xiang He obtained the degrees of B.Sc from Changchun College of Geology, China, in 1982 and M.Sc. from Qindao University of Oceanography, China, in 1986. He worked as an exploration geologist in geological companies searching for gold and base metals from 1986 to 1991, and received his Ph.D. degree from Department of Earth Sciences, Nanjing University, China in 1995. He is currently working in the Chinese Academy of Geological sciences, Beijing.

Pei Ni is Associate Professor at Department of Earth Sciences and director of fluid inclusion laboratory of State Key Laboratory for Mineral Deposit Research, Nanjing University, China. He obtained his Ph.D. degree of mineral deposits at Nanjing University in 1991 with a doctoral thesis on gold deposits and geological evolution of Liaodong Peninsula. His current research deals with ore geology and fluid processes, with particular interest in copper and gold deposits, carbonatite and granites in northern and eastern China.

Ke-Qin Xu was born in 1907. He received his degrees of M.Sc. in 1941 and Ph.D. in 1944 from the University of Minnesota. His main research includes geology of tungsten deposits, granites and related mineralisations, and strata-bound iron and base metal deposits. He is currently Professor of Department of Earth Sciences, Nanjing University and Academician of Academia Sinica. 